\title{
Elite culture: signs, features, examples
}

\author{
Shigabutdinova Dina Yasavievna \\ Bukhara State University \\ Lecturer, independent researcher of \\ Faculty of foreign languages (ESP) natural sciences department \\ amaze1985@mail.ru \\ $+998974886515$
}

\begin{abstract}
Elite culture (from the French elite - selective, best) can be defined as a subculture of privileged groups of society (sometimes their only privilege may be the right to cultural creativity or to preserve cultural heritage), which is characterized by value-semantic isolation, closeness; the elite culture asserts itself as the creativity of a narrow circle of "the highest professionals", the understanding of which is available to an equally narrow circle of highly educated connoisseurs.
\end{abstract}

Key words: Elite culture, society, cultural heritage, cultural creativity, folklore, minority.

\section{I.Introduction}

Elite culture claims that it stands high above the "routine" of everyday life and takes the position of the "highest court" in relation to the socio-political problems of society. Elite culture is considered by many culturologists as the antipode of mass culture. From this point of view, the producer and consumer of the elite cultural is the highest, privileged stratum of society - the elite. In modern cultural studies, the understanding of the elite as a special stratum of society endowed with specific spiritual abilities has been established. The elite is not just the upper stratum of society, the ruling elite. There is elite in every social class. The elite is the part of society most capable of spiritual activity, endowed with high moral and aesthetic inclinations. It is she who ensures social progress; therefore art should be focused on meeting her needs and demands.

\section{II.Literature review}

The main elements of the elite concept of culture are contained in the philosophical works of A. Schopenhauer ("The World as Will and Representation") and F. Nietzsche ("Human, Too Human", "Merry Science", "Thus Spoke Zarathustra"). A. Schopenhauer divides humanity into two parts: "people of genius" and "people of benefit." The former are capable of aesthetic contemplation and artistic activity, the latter are focused only on purely practical, utilitarian activity. The demarcation of elite and mass culture is associated with the development of cities, printing, the emergence of a customer and a performer in the field of art. Elite - for sophisticated connoisseurs, mass - for an ordinary reader, viewer, listener. Works that serve as a standard of mass art, as a rule, reveal a connection with folklore, mythological, popular prints that existed before. In the 20th century, Ortega-i-Gasset summed up the elite concept of culture. In the work of this Spanish philosopher "Dehumanization of Art", it is argued that the new art is addressed to the elite of society, and not to its mass. Therefore, it is absolutely unnecessary for art to be popular, generally understandable, universal. New art should alienate people from real life.

\section{III.Analysis}

"Dehumanization" is the basis of the new art of the 20th century. There are polar classes in society - the majority (masses) and the minority (elite). New art, according to Ortega, divides the public into two classes those who understand it and those who do not, that is, artists and those who are not artists. The elite, according to Ortega, is not a tribal aristocracy and not privileged strata of society, but that part of it that has a "special organ of perception." It is this part that contributes to social progress. And it is to her that artists should turn with their works. The new art should help to ensure that "... The best know themselves, learn to understand their mission: to 
be in the minority and to fight the majority." A typical manifestation of elite culture is the theory and practice of "pure art" or "art for art", which found its embodiment in Western European and Russian culture at the turn of the 19th and 20th centuries. For example, in Russia, the ideas of elite culture were actively developed by the art association "World of Art" (artist A. Benois, editor of the magazine S. Diaghilev, etc.). Elite culture, as a rule, arises in an era of cultural crisis, the breakdown of old and the birth of new cultural traditions, methods of production and reproduction of spiritual values, a change in cultural and historical paradigms. Therefore, representatives of elite culture perceive themselves as either "creators of the new", towering over their time, and therefore not understood by their contemporaries (most of them are romantics and modernists - figures of the artistic avant-garde who make a cultural revolution), or "keepers of fundamental foundations" who should be protected from destruction and the meaning of which is not understood by the "mass". In such a situation, elite culture acquires the features of esotericism - a closed, secret knowledge that is not intended for wide, universal use. In history, priests, religious sects, monastic and spiritual knightly orders, Masonic lodges, craft workshops, literary, artistic and intellectual circles, and underground organizations have acted as carriers of various forms of elite culture. Such a narrowing of potential addressees of cultural creativity gives birth to its carriers an awareness of their creativity as exclusive: "true religion", "pure science", "pure art" or "art for art." The concept of "elite" as opposed to "mass" was introduced into circulation at the end of the 18th century. The division of artistic creativity into elite and mass was manifested in the concepts of romantics. Initially, among the romantics, the elitist carries the semantic meaning of being chosen, exemplary. The concept of the exemplary, in turn, was understood as identical to the classical. The concept of the classic was especially actively developed during the Renaissance. Then the normative core was the art of antiquity. In this understanding, the classic was personified with the elite and exemplary. Romantics sought to focus on innovation in the field of artistic creation. Thus, they separated their art from the usual adapted art forms. The triad: "elite - exemplary - classical" began to crumble the elite was no longer identical to the classic.

A feature of elite culture is the interest of its representatives in the creation of new forms, a demonstrative opposition to the harmonious forms of classical art, as well as an emphasis on the subjectivity of the worldview.

The characteristic features of an elite culture are:

1. Striving for the cultural development of objects (phenomena of the natural and social world, spiritual realities), which stand out sharply from the totality of what is included in the field of subject development of the "ordinary", "profane" culture of the given time;

2. The inclusion of your subject in unexpected value-semantic contexts, the creation of its new interpretation, unique or exclusive meaning;

3. Creation of a new cultural language (language of symbols, images), accessible to a narrow circle of connoisseurs, the decoding of which requires special efforts and a wide cultural outlook from the uninitiated. Elite culture is ambivalent, contradictory in nature. On the one hand, elite culture acts as an innovative enzyme of the sociocultural process. The works of elite culture contribute to the renewal of the culture of society, bring into it new problems, language, methods of cultural creativity. Initially, within the boundaries of elite culture, new genres and types of art are born, the cultural, literary language of society is developed, extraordinary scientific theories, philosophical concepts and religious teachings are created, which, as it were, "break out" beyond the established boundaries of culture, but then can enter the cultural heritage of the entire society. Therefore, for example, they say that truth is born as heresy, and dies as a banality.

On the other hand, the position of an elite culture, opposing itself to the culture of society, may mean a conservative departure from social reality and its topical problems into the idealized world of "art for art," religious-philosophical and socio-political utopias. Such a demonstrative form of rejection of the existing world can be both a form of passive protest against it, and a form of reconciliation with it, recognition of its own impotence of elite culture, its inability to influence the cultural life of society. This duality of elite culture determines the presence of opposite - critical and apologetic - theories of elite culture. Democratic thinkers (Belinsky, Chernyshevsky, Pisarev, Plekhanov, Morris, etc.) were critical of elite culture, emphasizing its separation from the life of the people, its incomprehensibility to the people, and its service to the needs of rich, satiated people. At the same time, such criticism sometimes went beyond the limits of reason, turning, for example, from a criticism of elite art into a criticism of any art. Pisarev, for example, stated that "boots are above art."

\section{IV.Discussion}

L. Tolstoy, who created high samples of the novel of the New Time ("War and Peace", "Anna Karenina", 
"Sunday"), in the late period of his work, when he moved to the position of peasant democracy, considered all these works of his unnecessary to the people and became to compose popular stories from peasant life. Another trend in the theories of elite culture (Schopenhauer, Nietzsche, Berdyaev, Ortega y Gasset, Heidegger and Ellul) defended it, emphasizing its content, formal perfection, creative search and novelty, the desire to resist the stereotyped and lack of spirituality of everyday culture, considered it as a haven of creative individual freedom. A variety of elite art in our time is modernism and postmodernism. Mass and elite culture the concept of elite means the best. There is a political elite (a part of society with legitimate power), an economic elite, and a scientific elite. German sociologist G.A. Lansberger defines the elite as a group that significantly influences decisions on key issues of a national nature. UN Secretary General Dag Hammarskjöld believed that the elite is the part of society that is capable of taking responsibility for the majority of people.

Ortega-i-Gasset believed that the elite is the most creative and productive part of society, possessing high intellectual and moral qualities. In the context of cultural studies, we can say that it is in the elite sphere that the foundations of culture and the principles of its functioning are formed. The elite is a narrow stratum of society, capable of generating values, principles, attitudes around which society can consolidate and on the basis of which culture can function. Elite culture belongs to a special social stratum with rich spiritual experience, developed moral and aesthetic consciousness. One of the options for elite culture is esoteric culture. The very concepts of esotericism and exotericism are derived from the Greek words esoterikos - internal and exoterikos - external. Esoteric culture is available only to initiates and absorbs knowledge intended for a select circle of people. Exotericism presupposes popularity and general availability. The attitude in society towards elite culture is ambiguous. Culturologist Dr. Richard Staitz (USA) distinguishes 3 types of people's attitude to elite culture: 1) Estatism is a group of people who are not creators of elite culture, but they enjoy it and value it. 2) Elitism - they consider themselves to be an elite culture, but they are dismissive of mass culture. 3) Eclecticism - both types of cultures are accepted. One of the factors that exacerbated the need of the 19th century society to separate elite culture from mass culture is associated with the rethinking of the Christian religion, which offered those norms and principles that were accepted by all members of society. The rejection of the norms of Christianity meant the loss of a meaningful single ideal of absolute perfection, the absolute criterion of holiness. The need arose for new ideals capable of stimulating and guiding social development.

As a matter of fact, the split in people's minds of ideas about the value of a common Christian culture meant the splitting of society into social groups, cultures, subcultures, each of which adopted its own ideals, stereotypes and norms of behavior. Elite culture, as a rule, is opposed to mass culture. Let's highlight the main features that characterize both types of culture. Traits of an elite culture:

1. Constancy, that is, the products of elite culture do not depend on historical time and space. So, the works of Mozart from the moment of their creation are an example of classics at all times and in any state.

2. The need for spiritual work. A person living in an elite culture is called to intense spiritual work.

3. High requirements for human competence. In this case, it is meant that not only the creator, but also the consumer of the products of elite culture must be capable of intensive spiritual work, be sufficiently well prepared in the art criticism sense.

4. Striving to create absolute ideals of perfection. In an elite culture, the rules of honor and the state of spiritual purity acquire a central, pronounced meaning.

5. Formation of that system of values, those attitudes that serve as the foundation for the development of culture and the center of consolidation of society.

Features of mass culture:

1. The possibility of conveyor production of products related to culture.

2. Meeting the spiritual needs of the majority of the population.

3. The ability to involve many people in the social and cultural life.

4. Reflection of those behavioral models, stereotypes and principles that prevail in public consciousness at a given period of time.

5. Fulfillment of political and social order. 6. Incorporation into the mental world of people of certain patterns and patterns of behavior; creation of social ideals. It is important to take into account the fact that in a number of cultural systems the concept of elite culture is conditional, because in some communities the border between the elite and the masses is minimal. In such cultures, it is difficult to distinguish popular culture from elite culture. For example, many fragments of everyday life receive the academic status of a "source" only if they are remote from us in time or have an ethnographic and folklore character. 


\section{V.Conclusion}

In the modern world, the blurring of the boundaries between mass and elite culture is so destructive that it often leads to the devaluation of cultural heritage for subsequent generations. So, pop culture has affected all spheres of life, creating such phenomena as pop ideology, pop art, pop religion, pop science, etc., involving everything from Che Guevara to Jesus Christ into its space. Often pop cultures are perceived as a product of the culture of economically developed countries capable of providing themselves with a good information industry and exporting their values and stereotypes to the environment of other cultures.

\section{References:}

1. Nazarova D.I. The interpretation of educational ideas in the poems of Jamal Kamal// International Scientific Journal Theoretical \& Applied Science.- 2019.- №11.- Pp. 136 - 138.

2. Nazarova D.I. Literary Motives of Sufizm and Spiritual, Moral Ideas in the Lyrics of Jamal Kamal//International Journal of Recent Technology and Engineering (IJRTE).-2019.- №10.- Pp. 223 225.

3. Dilrabo Quvvatova, Nazarova D.I. The rubai genre in the works of Jamal Kamal// The American Journal of Social Science and Education Innovations.- 2020.- №9.- Pp. 346 - 352.

4. Nazarova D.I. Jamol Kamolning Asru radifli g'azaliga yozgan muxammasi// Ilim ham ja'miyet. Ilmiyuslubiy jurnal.- 2020.- №1.- Б. 93 - 94

5. Nazarova D.I. The foundation of Kamol Jamol's poems is pain// Conference of Management of Islamic Education Leadership In The Era of Revolution.- 2020.- №6.- Pp. 1 - 3.

6. Nazarova D.I. Feelings of lyric heroes in Kamol Jamol's work// Conference of Management of Islamic Education Leadership In The Era of Revolution.- 2020.- №6.- P. 1 - 3.

7. Akhmedova Mekhrinigor Bakhodirovna. (2020). "SPIRITUALITY" LANGUAGE CATEGORY AND ITS CONTENT. Middle European Scientific Bulletin, 6, 57-59. https://doi.org/10.47494/mesb.2020.6.115

8. Akhmedova Mekhrinigor Bakhodirovna. “'SPIRITUALITY' LANGUAGE CATEGORY AND ITS CONTENT". Middle European Scientific Bulletin, vol. 6, Nov. 2020, pp. 57-59, doi:10.47494/mesb.2020.6.115.

9. Akhmedova, M. B. (2019) "ANALYSIS OF —SPIRITUALITY\| CATEGORY AND ITS STRUCTURE IN THE ENGLISH LANGUAGE," Central Asian Problems of Modern Science and Education: Vol. 4 : Iss. 2 , Article 136.

10. Shigabutdinova D.Ya. THE POSITIVE NOTES IN THE DRAMATICS OF ATHOL FUGARD. ТЕОРИЯ И ПРАКТИКА СОВРЕМЕННОЙ НАУКИ. Номер: 5 (35) Год: 2018 СтраницЫ: 1128-1129 eISSN: 2412-9682

11. Dina Yasaviyevna Shigabutdinova, ISSUES OF APPLICATION OF THE MAIN PRINCIPLES OF COMPARATIVE LITERATURE IN THE STORY GENRE, Year: 2020 Issue: 05 Volume: 85 p-ISSN: 2308-4944 (print) e-ISSN: 2409-0085 (online)

12. Shigabutdinova D.Ya. THE POSITIVE NOTES IN THE DRAMATICS OF ATHOL FUGARD. ТЕОРИЯ И ПРАКТИКА СОВРЕМЕННОЙ НАУКИ. Номер: 5 (35) Год: 2018 СтраницЫ: 1128-1129 eISSN: 2412-9682

13. Dina Yasaviyevna Shigabutdinova, ISSUES OF APPLICATION OF THE MAIN PRINCIPLES OF COMPARATIVE LITERATURE IN THE STORY GENRE, Year: 2020 Issue: 05 Volume: 85 p-ISSN: 2308-4944 (print) e-ISSN: 2409-0085 (online).

14. https://center-yf.ru/data/stat/elitarnaya-kultura.php 